DOI:10.14258/tpai(2021)33(3).-13

УДК 902.2«6323»(517)

\title{
MICROBLADE PERCUSSION IN THE UPPER PALEOLITHIC OF MONGOLIA: ON THE PROBLEM OF ORIGIN AND DISTRIBUTION WITHIN CENTRAL ASIA AND THE FAR EAST
}

\author{
Andrey V. Tabarev, Sergey A. Gladyshev \\ Institute of Archaeology and Ethnography of the SB RAS, Novosibirsk, Russian Federation \\ ORCID: https://orcid.org/0000-0002-6249-8057, e-mail: olmec@yandex.ru \\ ORCID: https://orcid.org/0000-0002-7443-654X, e-mail: gladyshev57@gmail.com
}

\begin{abstract}
The focus of this investigation is on the technology of micro-percussion in the Upper Paleolithic of Mongolia. Micro-percussion is defined as the entire assemblage of lithic artifacts associated with the production of microblades. The complexes analyzed here include microcores and microblades, but not tools made of them. Until recently, microblade percussion has never been considered a distinct trend emergent in the lithic technology of the Early Upper Paleolithic of Mongolia. In this paper, based upon lithic materials from northern Mongolia and the Gobi Altai, we prove the existence of microblade percussion at the early stages of the Upper Paleolithic (37-26 000 $\mathrm{BP}$ ) and persisting until the very beginning of the Holocene (11-10 $500 \mathrm{BP})$. In other words, this is crosscutting technology for the region. We conclude that in the Early Upper Paleolithic complexes of northern Mongolia, preferential reduction initially emphasized narrow-front and, later, wedgeshaped microcore production. Analysis of materials from the Final Paleolithic and the Early Holocene horizons at the Tolbor- 15 site, along with representative surface collections and GIS modeling of site location patterns along tributaries of the Selenga River, allow us to formulate a series of hypotheses regarding the origin of the wedge-shaped flaking technique in northern Mongolia and the dynamics and directionality of its diffusion. The microblade technique observable in the Final Paleolithic of northern Mongolia exhibits more similarities with lithic complexes known archaeologically to the south (Inner Mongolia) and east (Russian Far East, Korean Peninsula, and Japanese Archipelago), not with the Russian Trans-Baikal region.

Keywords: Mongolia, Central Asia, Far East, Upper Paleolithic, microblade percussion

Acknowledgments: Research is supported by Russian Scientific Foundation, Project No. 19-1800003 "Neolithic Civilizations of Eurasia: Jomon, Japanese Archipelago - Origins, Early Stage, and Local Peculiarities". The authors express thanks to our colleagues Dr. Eugeny P. Rybin and Arina M. Khatsenovich for useful consultations and discussions regarding this article. We owe a special debt of gratitude to Anastasia Abdulmanova whose excellent illustrations are included in this publication. Pieces of advice on the article's style done by Prof. J. Olsen are priceless.
\end{abstract}

For citation: Tabarev A.V., Gladyshev S.A. Microblade Percussion in the Upper Paleolithic of Mongolia: on the Problem of Origin and Distribution Within Central Asia and the Far East. Theory and Practice of Archaeological Research. 2021;33(3): 240-259. (In English) DOI: 10.14258/tpai(2021)33(3).-13 


\title{
МИКРОПААСТИНЧАТОЕ РАСЩЕПАЕНИЕ В ВЕРХНЕМ ПАЛЕОАИТЕ МОНГОАИИ: К ВОПРОСУ О ПРОИСХОЖАЕНИИ И РАСПРОСТРАНЕНИИ В ЦЕНТРААЬНОЙ АЗИИ И НА ААА ЬHЕМ ВОСТОКЕ
}

\author{
А. В. Табарев, С. А. ГАадышев \\ Институт археологии и этнографрии СО РАН, г. Новосибирск, Российская ФеАерация \\ ORCID: https://orcid.org/0000-0002-6249-8057, e-mail: olmec@yandex.ru \\ ORCID: https://orcid.org/0000-0002-7443-654X, e-mail: gladyshev57@gmail.com
}

Резюме: Предметом исследования является технология микрорасщепления в комплексах раннего верхнего палеолита Монголии. Под микрорасщеплением подразумевается вся совокупность каменных артефактов, связанная с операциями по изготовлению микропластин. В рассматриваемых комплексах обнаружены как микронуклеусы, так и микропластинки, но орудий из них не найдено. До сих пор микрорасщепление как самостоятельное направление развития технологии обработки камня в раннем верхнем палеолите Монголии не рассматривалось. В статье на примере материалов из северной Монголии и Гобийского Алтая доказывается существование микрорасщепления уже на ранних этапах верхнего палеолита (3726 тыс. л.н.). Делается вывод, что в комплексах раннего верхнего палеолита северной Монголии предпочтение отдавалось торцовому, а затем клиновидному микрорасщеплению. Анализ материалов комплексов финального палеолита и раннего голоцена со стоянки Толбор-15 и представительных коллекций сборов с поверхности, а также ГИС модель распространения памятников вдоль притоков р. Селенги дают нам возможность сформулировать ряд гипотез о происхождении клиновидного микрорасщепления в северной Монголии, динамику и направление его распространения. Микропластинчатая техника финального палеолита северной Монголии демонстрирует большее сходство с комплексами, расположенными к югу (Внутренняя Монголия) и востоку (российский Дальний Восток, Корейский полуостров и Японский архипелаг), но не с Забайкальем.

Ключевые слова: Монголия, Центральная Азия, Дальний Восток, верхний палеолит, микропластинчатое расщепление

Благодарности: Исследование выполнено при финансовой поддержке РНФ, проект № 19-18-00003 «Неолитические цивилизации Евразии: Дземон, Японский архипелаг - происхождение, ранняя стадия и локальные особенности». Авторы выражают искреннюю благодарность своим коллегам Е.П. Рыбину и А. М. Хаценович за полезные консультации и дискуссии в ходе подготовки этой публикации. Мы также выражаем глубокую признательность А. В. Абдульмановой за прекрасно выполненные рисунки, использованные в статье. Редактура английского текста любезно выполнена профессором Д. Олсеном.

Для цитирования: Табарев А.В., Гладышев С.А. Микропластинчатое расщепление в верхнем палеолите Монголии: к вопросу о происхождении и распространении в Центральной Азии и на Дальнем Востоке // Теория и практика археологических исследований. 2021. Т. 33, №3. C. 240-259. DOI: 10.14258/tpai(2021)33(3).-13

\section{I} ntroduction

Materials of multi-level Paleolithic-Neolithic sites in Mongolia are of the highest importance for studies of the problem of the initial peopling by Homo sapiens of Northeast Asia in the Pleistocene. These data help correlating Mongolian artifacts with those of the 
detailed-excavated Baikal and Trans-Baikal territories, and to construct a unified picture of the development of the Paleolithic in Central Asia and Eurasia in whole. Starting in the late 1990s a large series of stratified multilevel sites was discovered and studied in Gobi Altai and northern Mongolia. Of special interest are the cave sites Tsagaan Agui, Chikhen Agui, and the open-air Chikhen-2 site in the Gobi Altai, along with Tolbor- 4 and Tolbor- 15 open sites in Khangai Mountains of northern Mongolia (Fig. 1). The authors of this paper were directly involved in the investigations of all these sites.

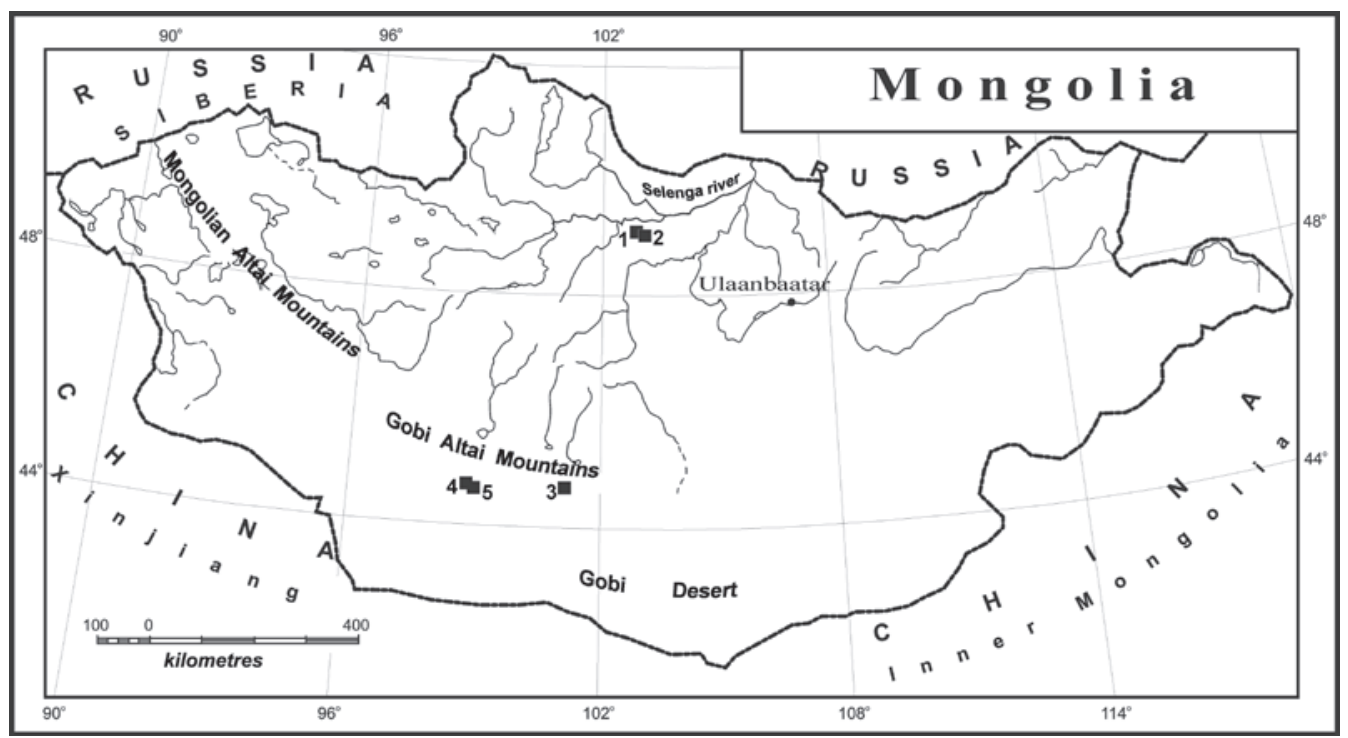

Fig. 1. Location of sites mentioned in the text: 1 - Tolbor-4; 2 - Tolbor-15;

3 - Tsagaan Agui Cave; 4 - Chikhen Agui Rockshelter; 5 - Chikhen-2

Рис. 1. Карта расположения стоянок, упомянутых в статье: 1 - Толбор-4; 2 - Толбор-15; 3 - пещера Цаган-Агуй; 4 - грот Чихэн-Агуй; 5 - Чихэн-2

Starting from 2014, excavations of the Early Upper Paleolithic in Northern Mongolia were led by the group of specialists from the Institute of Archaeology and Ethnography, Novosibirsk including Dr. Eugene P. Rybin and Dr. Arina M. Khatsenovich in permanent cooperation with specialists from Mongolia, Japan, USA etc. In fact they made important contribution to the quest of the origin and evolution of the Early Upper Paleolithic not only in Mongolia but in Central and Eastern Asia on the whole.

First of all, they re-organised previous periodization of the Early Upper Paleolithic of Mongolia by positioning "Initial" time of the Upper Paleolithic into the separate period on the basis of technological criteria [Rybin, 2014], and dividing the Early Upper Paleolithic into two periods with reasonable logic and arguments [Rybin et al., 2016a, 2016b].

The stratified Tolbor-21 (T-21) site is located in the same river valley as T-4 and T-15 (Ikh Tulberiin Gol), and Kharganyn Gol-5 located in the neighboring valley (Kharganyn Gol) sites plays central role in this concept. While in there researches were able to observe the archaeological horizons with the complexes of the Initial Upper Paleolithic and the Early 
Upper Paleolithic along with some archaeological materials below them. They logically concluded that lower horizons could belong to the Middle Paleolithic [Khatsenovich et al., 2017; Rybin, Khatsenovich, Pavlenok, 2016c; Khatsenovich et al., 2015]. Among the materials of Kharganyn-Gol-5 site A.M. Khatsenovich described a new specific type of tool - geometric microliths which earlier have never been found at the known stratified Paleolithic complexes of Mongolia [Khatsenovich and Rybin, 2015].

Also Rybin and Khatsenovich described several scenarios for the origin of the Initial and Early Upper Paleolithic periods in Mongolia which are connected not only with the spreading from the territories of Altai around 45000-30000 BP, but also the influence of the possible local Mongolian, the Middle Paleolithic component [Khatsenovich et al., 2015, 2017]. They published the most complete list of all the dates for all known stratified Paleolithic complexes in Mongolia [Rybin et al., 2016a, 2016b].

In turn, in our article, we review all data connected with micro-percussion in the Early Upper Paleolithic (EUP), the Final Paleolithic (FP), complexes, and the Final Upper Paleolithic (FUP) at multi-level sites in Mongolia. In other words, the subjects of this research are microcores and microblades found in these levels. EUP is presented by archaeological materials from Hors. 6, 5, and 4 at T-4 and Hors. 7, 6 and 5 at T 15 (Northern Mongolia); as well as archaeological complexes of the third depositional cycle in Tsagaan Agui, materials from Level 3 in Chikhen Agui Rockshelter, and materials from Levels 3 and 2.8-2.5 at the Chikhen-2 open-air site (Gobi Altai).

\section{Materials and Methods}

Six archaeological horizons lying directly above each other, without sterile layers, were distinguished in the cross-section of the Tolbor 4 site (T-4). Upper horizons ( 2 and 3 ) belong to the final stage of the Upper Paleolithic, while horizons 4, 5 and 6 (Hors. 4, 5, 6) are connected with the Early and the beginning of the Early Upper Paleolithic.

In its turn, seven archaeological horizons were recognized for Tolbor-15 site (T-15). Upper horizons of T-15 illustrate the Final Paleolithic and are dates between 15000-14000 BP. The Early Upper Paleolithic complex was located in horizons 5-7 and is dated to 34000$28000 \mathrm{BP}$.

Rich archaeological material, excavated during several seasons at T-4 and T-15 sites reasoned to judge about the technology of percussion and tools manufacture by the Upper Paleolithic habitants of this region [Derevianko et al., 2006, 2007, 2013; Rybin et al., 2006; Rybin, Gladyshev, Tsybankov, 2007; Gladyshev, Tsybankov, Kandyba, 2010; Gladyshev, Tabarev, Olsen, 2011].

In addition to archaeological material, a large series of ${ }^{14} \mathrm{C}$ dates covered the period from the Final Paleolithic to the limit possibilities of the method (the Early Upper Paleolithic) was received [Gladyshev et al., 2013]. In sum, the periodization of the Upper Paleolithic complexes of Mongolia, based on the radiocarbon dating and comparisons of the archaeological materials was proposed [Gladyshev et al., 2010, 2012].

However such important component of the stone industry as micro-percussion turned out to be unexplored. We understand micro-percussion as the specific part of ancient human activity, and direction lithic technology focused on the production of micro-preforms (microblades). It includes micro-cores of various types itself and micro-preforms removed from them. The 
study of this topic will be realized in frames of the morphological, and technico-typological methods along with historical correlation method.

Archaeological Materials Associated with Micro-percussion from Early Upper Paleolithic Complexes of Northern Mongolia and the Gobi Altai

Sixty-six microcores were identified in the collection of Hors. 6 and 5 at T- 4 site. The most numerous group consists of narrow-front microcores (48 items). They all have front on the narrow side of the core. They could be divided into two types according to the preform and technique of the percussion.

The first type is represented by narrow-front microcores made on edge spalls from big sub-prismatic cores - so called "core-burins" (15 items). New platform beveled to the back side of the spall usually was prepared by retouch on one or two margins of these spalls; microblades were removed from this platform along the lateral (Fig. 2.-1-4). The direct analogies of these cores occur in complex of Kara-Bom site (Russian Altai Region), where they were the subject of long-term discussion to be recognizes as "cores" or "burins". Finally researchers came to agreement that these artifacts are special-type microcores on technical spalls focused for the production of elongated bladelets and microblades [Slavinsky, Rybin, Belousova, 2016].

The second type is documented by narrow-front microcores made on various spalls of mid-range size (33 items). To remove the microblades and narrow bladelets ancient knappers used natural facets or laterals (Fig. 2.-5, 6). Six examples were made on small pebbles or pebble fragments, while for the rest, flakes were used. Maximal measurements for the cores are $56 \times 37 \times 18 \mathrm{~mm}$, minimal $-40 \times 17 \times 14 \mathrm{~mm}$. To initialize the percussion the removals were done along the lateral (in case of spall preform), or the natural facet of the stone. Slightly convex front demonstrates the negatives of single-directional removals of bladelets and microblades, platforms are beveled to the opposite side of the front which is prepared by punctual retouch.

One of the microcores morphologically is very similar with the conical microcores (Fig. 2.7). It is made on the flake of the sub-rectangular configuration and oval cross-section with some cortex remnants. Its platform was prepared by the series of removals and canted to the ventral surface of the initial flake; front demonstrates traces of single-directional removals of bladelets and microblades.

The other narrow-front microcore is close to wedge-shaped modification. Being made on the elongated pebble it has cylindrical cross-section; traces of single-directional bladelets-like removals are located on the narrow side. Negatives cover about the half of it, and abut to the base of the core designed into the two-side retouched edge. It looks like the accommodation to tight the core into any portable device. From the other hand, this retouched edge is not opposed to the front of percussion, which is typical for classic wedge-shaped microcores, but in the same plane position (Fig. 2.-8). 


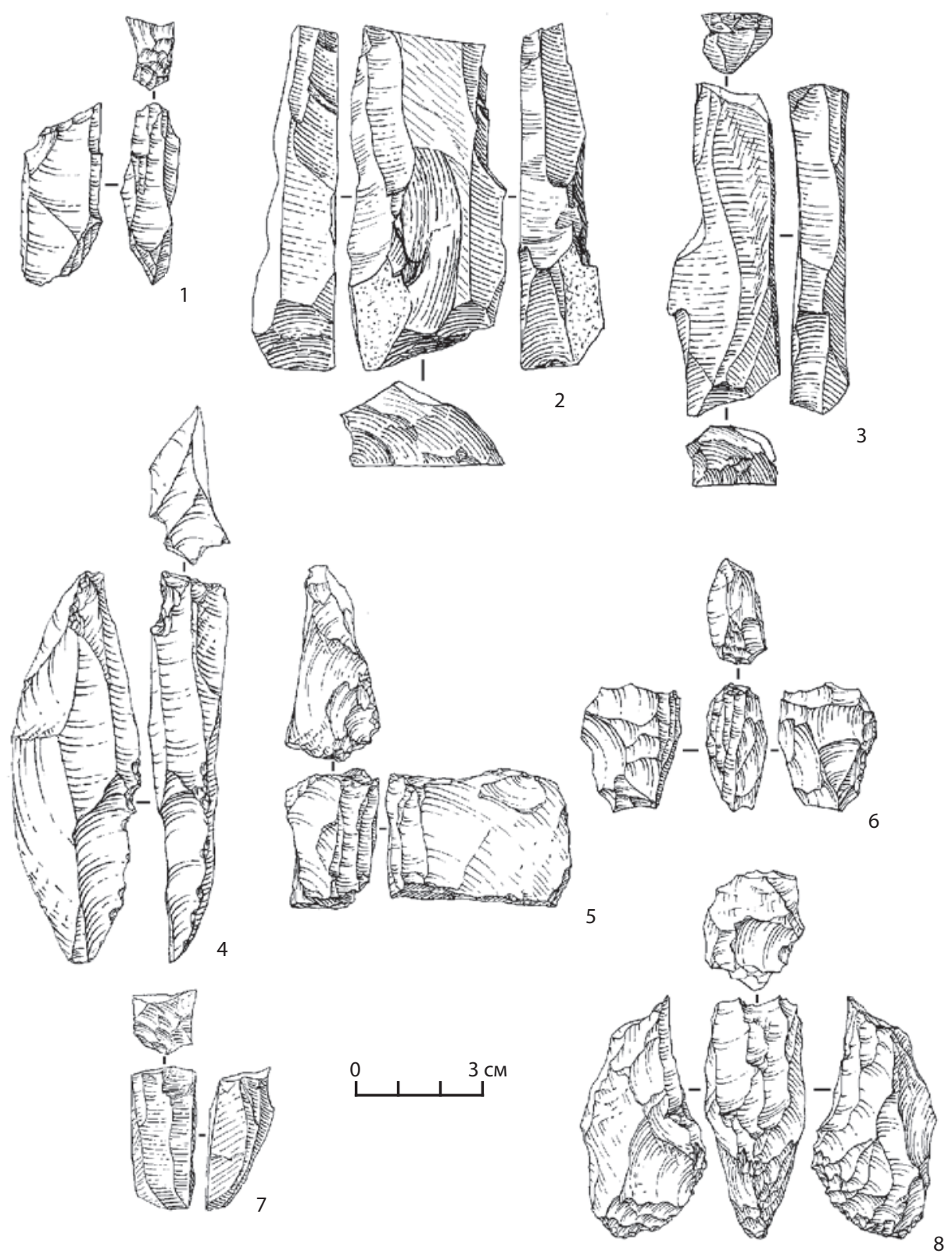

Fig. 2. Narrow-front microcores: 1-4-microcores-burin type (1, 4-Tolbor-4, Hor. 6;

2, 3 - Tolbor-4, Hor. 5); 5-7 - narrow-front microcores (5, 7 - Tolbor-4, Hor. 5; 6 - Tolbor-4, Hor. 6); 8 - proto-microcore (Tolbor-4, Hor. 5)

Рис. 2. Торцовые микронуклеусы: 1-4 - микронуклеусы-резцы (1, 4- Толбор-4, гор. 6;

2, 3 - Толбор-4, гор. 5); 5-7 - торцовые микронуклеусы (5, 7 - Толбор-4, гор. 5; 6 - Толбор-4, гор. 6); 8 - прото-микронуклеус (Толбор-4, гор. 5) 
Next type of microcores known in Hors. 6 and 5 at T-4 site is documented by monofrontal and two-platform flat microcores with parallel removal of microblades (22 items). This type has analogies in collections of some sites of the EUP in South Siberia. Usually they are of small size within compact measurements ( $\max -49 \times 52 \times 16 \mathrm{~mm}$, min $-36 \times 36 \times 19$ $\mathrm{mm})$, rectangular in configuration, flat in cross-section. All of them were prepared on spalls or fragments of spalls, with just one exception of the core on the initial stage of exploration made on a single piece of raw material. The whole series of cores strongly confirms that this type is no the product of the bigger cores exhaustion, but belongs to the original chaîne opératoire. For example, one core retains cortex on part of the front and the opposite side; another is prepared on the small flake with the central ridge formed by vertical retouch on the dorsal surface. The third one, with the platform prepared on the spall with retouch on the narrow edge, showed the percussion which started with the elimination of one of the laterals, and subsequent removals of two microblades on the ventral face of the core.

Among the cores illustrating the next stage of the exploration there are three artifacts of double-platform type. All exhibit the negative scars of microblade removals with irregular shape (Fig. 3.-1). Usually one of the laterals was partly sharpened by retouch, while the other stayed wider. One of the cores of this type is presented in the picture (Fig. 3.-2). Another example (Fig. 3.-3) shows the process of transition of the percussion to the narrow side where the removals of microblades continued from the platform with the alternative orientation in comparison with the wide front. Flat retouch on the opposite side of the core is a common technical characteristic for this type of the cores.

The last, the forth type of the microcores, known in the EUP complexes at T-4 site is represented by one artifact. This is a very small sub-prismatic double-platform microcore (Fig. 3.-4). Each front of percussion was turned into the platform for the subsequent series of removals. The opposite side of the core is covered by natural cortex.

Analyzing these materials we could suggest that the preference in microblades production during the Initial Upper Paleolithic in northern Mongolia was given to the percussion of narrow-front cores. It should be underlined that "burin-cores" were in use only with the frames of this period, there are no technological signals about their presence in later times.

Later period of EUP in Northern Mongolia is characterized by the materials from Hors. 7-5 at T-15 site and Hor. 4 at T-4 site. It is dated by ${ }^{14} \mathrm{C}$ in chronological frames from 33000 to $26000 \mathrm{BP}$. The earliest materials are situated in Hors. 7-5 at T-15 site. Micro-percussion in these horizons is represented by three types of microcores.

The first type, microcores made of various preforms (13 items), are small flakes ( 9 items) and single briquettes ( 4 items). These microcores have minimal initial treatment by a series of removals to prepare striking platform, or even without it. After that several small microblades were removes from one of the preforms edges.

One of the microcores is presented by double-platform single-front modification on the briquette preform. Microblades were removed first from one platform, and then from the other in the opposite direction. 

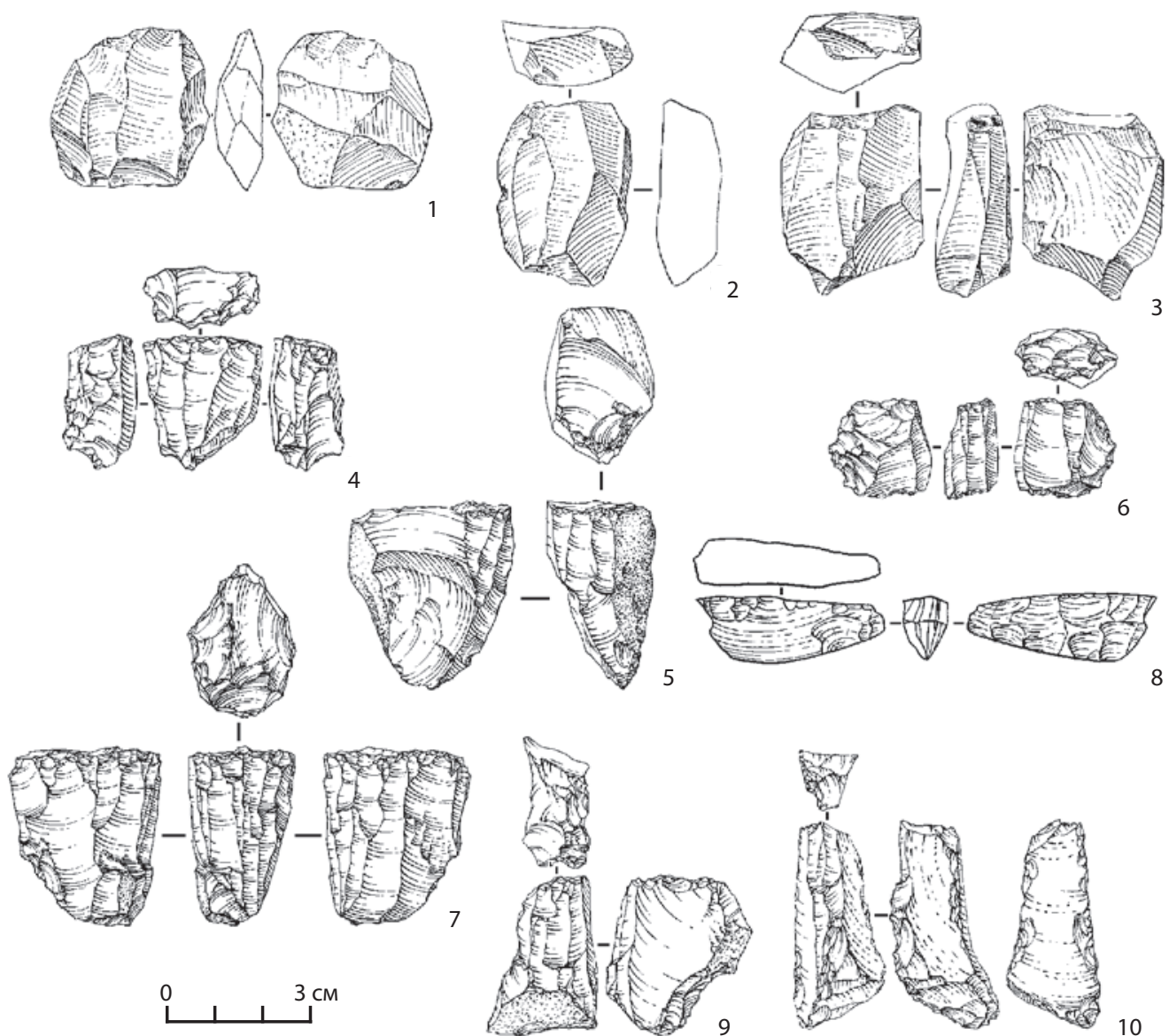

Fig. 3. Flat, volumetric, narrow-front, and wedge-shaped microcores: 1-3-flat microcores

(Tolbor-4, Hor. 5); 4, 9, 10 -volumetric sub-prismatic microcores (4 - Tolbor-4, Hor. 6;

9, 10 - Tolbor-4, Hor. 4); 5, 6- narrow-front microcores (Tolbor-15, Hor. 6);

7, 8 - wedge-shaped microcores (Tolbor-15, Hor. 5)

Рис. 3. Плоскостные, объемные, торцовые и клиновидные микронуклеусы: 1-3 плоскостные микронуклеусы (Толбор-4, гор. 5); 4, 9, 10 - объемные подпризматические микронуклеусы (4 - Толбор-4, гор. 6; 9, 10 - толбор-4, гор. 4); 5, 6-торцовые микронуклеусы (Толбор-15, гор. 6); 7, 8 - клиновидные микронуклеусы (Толбор-15, гор. 5)

The second type includes two artifacts of triangle configuration and flattened crosssection. They could be recognized as proto-wedge-shaped cores for microblades production. The shape of the microcore was determined by the shape of the initial preform: in one case it was the flake, in two others - possibly, very exhausted cores for bladelets. Platforms were prepared by the series of removals, while the opposite sides were shaped into the wedge by retouch. According to the negatives on the front the cores were used for microblades and small bladelets (Fig. 3.-5, 6). 
The third type of microcore are wedge-shaped microcores for producing microblades (two items). One of the cores is made on a small pebble. Platform was prepared by several centripetal removals and oriented perpendicular to the front. The opposite support side was sharpen into wedge by retouch, on one of the laterals remained the portions of cortex (Fig. 3.-7). Another microcore was manufactured from the triangle edge spall; natural surface was used for the platform. One of the laterals has total surface retouching from the platform side, the other one was just slightly modified by retouch. The opposite side was carefully sharpened into wedge; the angle between front and platform is close to optimal - about $60^{\circ}$. According to the negatives $(1,2-1 \mathrm{~cm}$ length and $4 \mathrm{~mm}$ width), after several removals of the microblades the front was blocked by defects (breakage of microblades), and the exploration of the core was stopped on the early stage (Fig. 3.-8). We think that such problems in the core exploration are typical for pressure technique, and the core was reduced by pressure [Gladyshev and Tabarev, 2009]. This is confirmed, first of all, by the absence of any defects on the edge of the platform (they are common for percussion), and, secondly, by the equal width of the microblade across the length. In case of percussion, the width of the proximal end of the microblade, and accordingly, of its negative, will be bigger than at the distal end. And, finally, the core is so small (length $-5 \mathrm{~cm}$, front height $-1,8 \mathrm{~cm}$, and platform width $-1,4 \mathrm{~cm}$ ) that is not possible to reduce it further by either direct or even indirect percussion.

The further development of the micro-technique is illustrated by the materials from Hor. 4 at the T-4 site, which are dated between 27000-26000 BP. It should be noted that in whole the system of percussion in this horizon differs from Hors. 6-5. Firstly, occasional percussion is dominating which is evident by the production of flakes with irregular configuration and orthogonal treatment. There are also a lot of debitage forms of different size. In spite of the same stone tool-kit as in previous period, the changes in the system of percussion could be explained by the exploration of alternative raw material sources of more fractional nature. Secondly, the dramatically decrease of blade production and the total absence of sub-prismatic cores focused on manufacturing large and medium blades which are typical of the lower horizons.

Volumetric sub-prismatic microcores for microblade manufacture are characteristic of the second, later period of EUP in Northern Mongolia. This type is presented in the collection of Hor. 4 at the T- 4 site by eight items. All were made on small pebbles or spalls, three microcores have straight platforms (Fig. 3.-9), the rest ones - slanting platforms, all of the platforms were prepared by several removals and fixed by the edge with additional retouch. The front of percussion is covered by the negatives of bladelets; the opposite side is usually flat while the basal part of the core is slightly sharpened. One of the cores on the initial stage of percussion is of interest. It was made from end scraper which was possibly picked up somewhere and renewed later into the microcore. The difference in color and period of production between the negatives of microblades and prepared platform and the rest surface of the artifact with distinctive patina confirm it (Fig. 3.-10).

The second type of the microcores in the Hor. 4 at the T- 4 site - wedge-shaped microcores for microblade production (four items). Medium spalls were used as preforms for three cores, and the rest one was made from the small flat piece of local stone. In all cases, preliminary 
preparation started with the series of short removals for platform setting on one end of the preform. After that microblades were removed from the narrow side.

So, in materials belonging to second period of the EUP of northern Mongolia (Hors. 7-5 at T-15 the site, and Hor. 4 at the T-4 site) four types of microcores were identified: narrowfront, volumetric sub-prismatic, proto-wedge-shaped, and wedge-shaped cores.

Next categories of artifacts which characterize the micro-technology are microblades. They make up an insignificant part of all the removals.

We intentionally give the percentage neither for microcores nor for microblades of the total number of cores and removals of the other groups and types at the sites of northern Mongolia because this part is less than one percent. Analysis of the microblades demonstrates that unbroken artifacts are very few, the majority is fragmented. Most of the micro-spalls have pinpoint platforms; the margins are usually twisted, irregular, and convergent. There is no regularity in the dorsal treatment of the microblades, dihedral dorsal morphology is dominating. Single microblades with the trapezoidal cross-section and trihedral dorsal morphology are also known in the most ancient complexes (Hors. 6 and 5 at T- 4 site), and in some later ones (Hors. 7-5 at T-15 site and Hor. 4 at T-4 site). No traces of secondary retouch on the microblades or on their fragments were found.

Next region of Mongolia where evidences of the micro-percussion is known at the multilevel sites is Gobi Altai. Today for this territory there are just three stratified sites which belong to the EUP: Chikhen Agui Rockshelter, the Chikhen-2 open-air site, and Tsagaan Agui Cave. All these sites are multicomponent [Derevianko et al., 2000, 2001, 2015].

In Tsagaan-Agui Cave, clear evidence of micro-percussion is associated with the third cycle of the sedimentation. First, collections of Levels 3-5 from the Main Chamber which the researchers attributed to the Late Mousterian - the beginning of the UP period [Derevianko et al., 2000]. They emphasize that: "Some core-like artifacts demonstrate the negatives of the micro-removals done without any preliminary platform and front preparations" [Ibid.: p. 31]. Also they wrote that the traces of proto-wedge-shaped technology and micro-preforms production were recorded earlier, in the materials of the second cycle of the sedimentation (levels 6-11 in the Main Chamber), and could belong to the Middle Paleolithic [Derevianko et al., 2000: 30, Fig. 6.-7]. The only proto-wedge-shaped core was manufactured on the piece of raw materials without any preparation of the laterals; elongated platform was designed by big flat flakes, and the micro-removals from this core had elongated and convergent configuration. The collection from the third cycle of the sedimentation has wide time-frames: Level $4-$ from 66000 to 49000 BP, Level 3-33000-30000 BP [Derevianko et al., 2000: 27].

In Chikhen Agui Rockshelter, EUP materials were found in the third lithological horizon lying directly on the rock basement. The Paleolithic complex preserved on a small depression in the filling of the rocky base. On the rest of the territory of the cave it was destroyed [Derevianko et al., 2001]. In the collection there is one sub-prismatic core which typologically is the microcore for the microblade production [Derevianko et al., 2001: 30, Fig. 7.-7]. Its straight platform was neatly prepared with short flat removals; the edge of the platform was additionally fixed with micro-retouch; negatives of the microblade removals are visible on the front. Along with the microcore 24 microblades there are in the collection, their width is less 
than $0.7 \mathrm{~cm}$, and margins from the dorsal view are parallel. This lithic complex of the EUP is dated about 27000 BP [Derevianko et al., 2001: 34].

At the stratified Chikhen-2 open-air site, an EUP industry was discovered in Levels 3 and 2; at that level 2 is divided into 8 strata where $2.8-2.5$ belong to the EUP, and the upper levels to the later time [Derevianko et al., 2015]. Traces of the micro-percussion were found already in the collection of Level 3. The researchers point on the presence of microblades and bladelets with regular dorsal morphology [Derevianko et al., 2015: 21, Fig. 3.-9, 10] which in spite of the absence of the microcores could suggest the developed micro-percussion technology.

The next manifestation of the micro-percussion is known in the strata 2.6. There is a core in this strata demonstrating elements typical for the wedge-shaped cores [Derevianko et al., 2015: 32, Fig. 8.-4], and technical spall of so-called "ski-spall" modification [Derevianko et al., 2015: 33, Fig. 10.-18]. This artifact is a strong argument about the existence of the wedgeshaped technology in the industry of strata 2.6.

The most reliable example which confirms the fully developed technique of the manufacture and reduction of the microcores was found in strata 2.5. This is a microcore with scrupulous treatment of the laterals and prepared platform; microblades were removed from the narrow front and, partly, from one of the laterals [Derevianko et al., 2015: 34, Fig. 12.-5]. Furthermore, short narrow front microcore on the flake with the platform prepared by single removal was found in the same level [Derevianko et al., 2015: 34, Fig. 11.-3]. The lithic industry in stratum 2.5 dates to as early as 30000 BP [Derevianko et al., 2015: 37], so it is logical to assume that the materials in the lower strata of Level 2, and of Level 3 in particular, should be much older.

In the EUP materials of the Gobi Altai, two groups of the microcores were identified: subprismatic microcores (Chikhen Agui Rockshelter), and narrow-front modifications - wedgeshaped microcore (Chikhen-2 site), and short narrow-front microcores (Tsagaan Agui Cave, Chikhen-2 site).

The nearest complexes with synchronous industries of the EUP are the multilevel T-4 (Hor. 4), and T-15 sites (Hors. 7-5). Materials belonging to the period between 33000 and $30000 \mathrm{BP}$ are known in Hors. 7-5 at the T-15 site [Gladyshev and Tabarev, 2017].

Microblade Technologies in the Final Pleistocene and Early Holocene Industries of Northern Mongolia

Materials associated with the Pleistocene - Holocene transition were also studied and analyzed, but not in all detail. They are known from the upper levels at T-4 (Hors. 1-3), T-15 (Hors. 1-4), and Kharganyn Gol-5 (Hor. 3). From the other side, the degree of the discussion about these complexes is much lower. In fact, they were studied in a "passing regime", just because of their presence at the multi-level sites, but never were the goal of the special research project or survey.

The manifestation of microblade technology in the Paleolithic of northern Mongolia is documented, first, with wedge-shaped microcores, which were manufactured by the pressure technique. As it was mentioned above, the pilot signal of this technique (microcore) is known at T-15 in Hor. 5 with an associated AMS date of 28460 310 (AA-84137) [Gladyshev, Tabarev, Olsen, 2011]. This early age was skeptically accepted by some specialists who pointed on possible infiltration of this artifact from the overlapping strata. Such approach would be compelling only if a series (or even a single case) of such microcores were ever found in the 
upper horizons. However, while this was not fixed at T-15 or any other sites in the vicinity, we prefer to propose the early appearance of microblade pressure technique about 28000-27000 $\mathrm{BP}$ which is the earliest manifestation of this technology not only in northern Mongolia but in Central and East Asia as a whole.

Within the late period, at T-15, in Hors. 4, 3 (15000-14000 BP) and Hor. 2 (13000-11000 BP) wedge-shaped microcores are represented in more technically developed formats - on uni- and bifacial preforms. They all disappeared in Hor. 1 (the Early Holocene), while microblade technology continues to be in use in the form of micro-prismatic and micro-conical cores.

Interestingly to note that all the Final Paleolithic locations with microblade materials (microblade cores with negatives of removals, exhausted cores, microblades and their fragments, bi-facial and uni-facial preforms, boat-shaped and ski-spalls etc.) were located at different altitudes than locations yielding the Upper or Early Upper Paleolithic finds. From the other side, there are no wedge-shaped microblade cores (with pressure technique) in the upper horizons of such multi-component sites as T-4, 16 and 21 where micro-technology is represented by cores reduced only by percussion [Gillam et al., 2014].

In all known surface collections wedge-shaped microcores are usually accompanied by micro-conical and micro-prismatic modifications. So, the areas of habitation and activities of Final Paleolithic and Early Holocene groups in the Selenga River valley were identical.

This last point prompts returning to the question of the nature of the transition from the wedge-shaped to micro-prismatic technology. As it was emphasized above, these two technologies have not thus far been encountered in a single horizon in the Tolbor complex sites, which suggests the replacement of one by the other. This situation was encountered only at one site - T-15. Within special research wedge-shaped and micro-prismatic modifications could be traced, and their co-existence on the border of the Pleistocene and the Holocene would be prooved. This does not conflict with experimental data and strong evidence that to reduce wedge-shaped and micro-prismatic cores, portable devices of different constructions were used [Tabarev, 2012].

So far, only nine AMS dates are known for this period; they can be divided into two groups - the Final Pleistocene and the Holocene. Within the Final Paleolithic dates, five were obtained on Struthio eggshell and two on bone, while both Holocene dates were generated from charred remains on pottery. All the radiocarbon determinations in the first group fall within the range of 15700-12800 BP (18900-15200 cal BP), they completely match the Final Paleolithic. The second group - 7700-6700 BP (8600-7600 cal BP) corresponds with the Neolithic; possibly the Early Neolithic, because, for the present, they are the most ancient radiocarbon determinations not only the Selenga River basin but for the whole territory of Mongolia. Looks like in here we are facing gap between the two groups of dates - about 5000 - and it is possible that the degradation, the disappearance of wedge-shaped microblade technology, and its replacement by micro-prismatic technology occurred during this period.

It should be taken into consideration that chronological and regional subdivisions of microblade industries in the Trans-Baikal region often reflect the extent of archaeological knowledge,along with the clear intension of each scholar to contribute something original (personal) into this problem, or to critique previous models. Beginning in the 1990s, we observe the appearance of the so-called "Studenovskaya Culture" (18000-10800 BP); "Chikoiskaya 
Culture” (15000-11000 BP); “Old Chikoiskaya Culture” (20000-18000 BP), “Selenginskaya Culture" (18000-8000 BP); “Ust' - Menza Phase" (18000-13000 BP); and "Final Paleolithic Selenginskaya Culture" (13000-11000 BP) among others. Both variants - that microblade wedge-shaped cores technology penetrated the Trans-Baikal region from northern Mongolia and vice versa - are discussed in these constructions. Almost all specialists regard the Selenga River as the principal route of these migrations and concomitant exchange of technologies.

During archaeological surveys conducted in the Ikh Tulberiin Gol, Kharganyn Gol and Altaatyn Gol river valleys in 2011-2014, it was figured out that the real mobility of groups was not limited only to the so-called "Selenga Corridor," but on the contrary people preferred to use low mountain passes to conveniently and comfortably pass from one river valley to the neighboring one. If so, tributaries of the Selenga River were functional transitional paths from the river's upstream reaches to its mouth.

\section{Conclusions}

Summing up, we may conclude that in Central Asia (specifically, in Mongolia) micropercussion existed as an important element of material culture even during the early stage of the Upper Paleolithic. Technological approaches to microcore production and exploration appeared as early as 37000-35000 BP. Typology of microcore was not stable yet, there was a quest for optimal forms and shapes, while the morphology of small cores copies the morphology of large, flat and volume prismatic cores for blades and bladelets. The preference for narrow-front forms is obvious. The further development of the micro-technology continued until ca. 34000-33000 BP with the appearance of proto-wedge-shaped and wedge-shaped cores. The first evidence of the pressure technique also occurred at the same time or a little bit later.

We believe that the appearance of the micro-technique was not accidental, but reflected the necessity for smaller elements and microblades for composite tools which was manifest throughout Central Asia around 40000-35000 BP. Being spotted almost throughout the EUP, micro-percussion does not have an episodic but rather a crosscutting character.

Examples of the appearance and utilization of various micro-percussion techniques can be illustrated by caréné-type percussion in the Early Upper Paleolithic complexes of the Near East, Iran, and western Central Asia (Uzbekistan, Tajikistan) [Kolobova, Krivoshapkin, Pavlenok, 2014]; or narrow-front, flat-volume, and wedge-shaped percussion in the Russian Altai and Mongolia.

These facts confirm that the original technique of micro-percussion of narrow-front microcores came into practice in Mongolia as early as 40000-37000 BP. About 30000-28000 BP this approach transformed into the wedge-shaped technique based on the use of flakes, spalls, and bifacies as preforms. On the other hand, the same facts indicate the multi-linear and composite character of this process when several types of micro-percussion co-existed in the same territory simultaneously.

We contend that from morphological and typological points of view, the microblade technique in the Final Paleolithic of northern Mongolia illustrates interesting similarities with assemblages studied archaeologically to the south. For example, it is reasonable to mention the rich collections of Sven Hedin's Sino-Swedish Expeditions in Inner Mongolia; while to the east, the famous Here-Uul Mountain site is of special importance. Further east yet, we 
find analogies in the Ustinovka Industry (Maritime Region, Russian Far East), on the Korean Peninsula, and in the Japanese Islands [Gladyshev, Tabarev, 2020; Sato, Izuho, Morisaki, 2011].

In fact, the majority of similarities (especially within the technical spalls and forms of exhausted microcores) could link northern Mongolia materials with the obsidian industry of Fukui Cave (Nagasaki Prefecture, Kyushu) [Kanomata et al., 2015].

This information proves the most likely spreading of pressure microblade technology in the Upper Paleolithic from Central Asia (northern Mongolia, in particular) to coastal and island territories of the East Asia. We believe that the alternative direction proposed recently by Buvit and colleagues [2016] this far lacks adequate archaeological substantiation. Also it would be extremely important to verify the hypothesis of the local center of the appearence of the microblade technology on the Korean Peninsula and the scale of its influence on the territories of the Maritime Region, Russian Far East and the Japanese Islands.

\section{REFERENCES}

Buvit I., Izuho M., Terry K., Konstantinov M. V., Konstantiniov A. V. Radiocarbon Dates, Microblades and Late Pleistocene Human Migrations in the Transbaikal, Russia and the PaleoSakhalin-Hokkaido-Kuril Peninsula // Quatenary International. 2016. Vol. 425. P. 100-119. DOI: 10.1016/j.quaint.2016.02.050

Derevianko A.P., Gladyshev S. A., Olsen J. W., Petrin V.T., Tserendagva Y. Characteristic Features of the Chikhen Agui Lithic Assemblage (Gobi Altai) // Archaeology, Ethnology \& Anthropology of Eurasia. 2001. Vol. 5. P. 25-39.

Derevianko A.P., Zenin A. N., Rybin E. P., Gladyshev S. A., Tsybankov A. A. Razvitie kamennyh industrij verhnego paleolita Severnoj Mongolii (po dannym stoyanki Tolbor) [Evolution of Lithic Industries in the Upper Paleolithic of Mongolia (by the data of Tolbor 4 Site)] Chelovek i prostranstvo v kul'turah kamennogo veka Evrazii [Man and Space in the Stone Age Cultures of Eurasia]. Novosibirsk : Izd-vo In-ta arheologii i etnografii SO RAN, 2006. P. 17-42 (In Russ).

Derevianko A.P., Zenin A.N., Rybin E.P., Gladyshev S.A., Tsybankov A. A., Olsen D., Tseveendorj D., Gunchinsuren B. The Technology of Early Upper Paleolithic Lithic Reduction of Northern Mongolia: the Tolbor-4 Site // Archaeology, Ethnology \& Anthropology of Eurasia. 2007. Vol. 29. P. 16-38.

Derevianko A. P., Markin S. V., Gladyshev S. A., Olsen D. The Early Upper Paleolithic of the Gobi Altai Region in Mongolia (Based on Materials from the Chikhen-2 Site) // Archaeology, Ethnology \& Anthropology of Eurasia. 2015. Vol. 3 (43). P. 7-41. DOI: 10.1016/j. aeae.2015.11.004

Derevianko A.P., Olsen D., Tseveendorj D., Krivoshapkin A. I., Petrin V. T., Brantingham P. J. The Stratified Cave Site of Tsagaan Agui in the Gobi Altai (Mongolia) // Archaeology, Ethnology \& Anthropology of Eurasia. 2000. Vol. 1. P. 23-36.

Derevianko A.P., Rybin E.P., Gladyshev S. A., Tsybankov A. A., Gunchinsuren B., Olsen D. 2013. Early Upper Paleolithic Stone Tool Technologies of Northern Mongolia: the Case of Tolbor-4 and Tolbor-15 // Archaeology, Ethnology \& Anthropology of Eurasia. 2013. Vol. 4 (56). P. 21-37. 
Gillam J. C., Gladyshev S.A., Gunchinsuren B., Olsen J. W., Tabarev A. V., Rybin E. P. Update on Paleolithic Research in Northern Mongolia // Legacy. 2014. Vol. 2. P. 22-23.

Gladyshev S. A., Gunchinsuren B., Jull A. J., Dogandzic T., Zwyns N., Olsen J. W., Richards M.P., Tabarev A. V., Talamo S. Radiouglerodnoe datirovanie paleoliticheskih stoyanok v doline r. Ih-Tulberijn-Gol v Severnoj Mongolii [Radiocarbon Dating of Paleolithic Sites in the Ikh Tulberiin Gol River Valley, Northern Mongolia]. Vestnik NGU. Seriya: Istoriya, filologiya [Newsletter of Novosibirsk State University, Series History, Philology]. 2013. Vol. 12. Pp. 44-48 (In Russ).

Gladyshev S. A., Olsen J. W., Tabarev A. V., Kuzmin Y. V. Chronology and Periodization of Upper Paleolithic Sites in Mongolia // Archaeology, Ethnology \& Anthropology of Eurasia. 2010. Vol. 3 (43). P. 33-40.

Gladyshev S.A., Olsen J.W., Tabarev A. V., Jull A. J. The Upper Paleolithic of Mongolia: Recent Finds and New Perspectives // Quatenary International. 2012. Vol. 281. P. 36-46. DOI: 10.1016/j.guaint.2012.01.032

Gladyshev S. A., Tabarev A. V. New Data on the Early Upper Paleolithic of Northern Mongolia // Current Research in the Pleistocene. 2009. Vol. 26. P. 17-18.

Gladyshev S. A., Tabarev A. V. Nekotorye problemy izucheniya mikroplastinchatogo rasshchepleniya v rannem verhnem paleolite Severnoj Mongolii [Some Problems of Studies of Microblade Percussion in the Early Upper Paleolithic of Northern Mongolia]. Teoriya i praktika arheologicheskih issledovanij [Theory and Practice of Archaeological Research]. 2017. Vol. 17. Pp. 154-166. DOI: 10.14258/tpai(2017)1(17).-11 (In Russ)

Gladyshev S. A., Tabarev A. V. Zaselenie Yaponskogo arhipelaga i osobennosti kamennyh industrij pozdnego paleolita sopredel'nyh territorij: obzor sovremennoj problematiki [Peopling of the Japanese Archipelago and Peculiarities of the Late Paleolithic Lithic Industries of the Neighboring Territories: Overview of the current problematic]. Stratum plus. 2020. Vol. 1. Pp. 117-136. (In Russ).

Gladyshev S.A., Tabarev A. V., Olsen J. W. Itogi izucheniya verhnego paleolita Severnoj Mongolii [Results of the Study of the Upper Paleolithic of Northern Mongolia]. Vestnik NGU. Seriya: Istoriya, filologiya [Newsletter of Novosibirsk State University. Series: History, Philology]. 2011. Vol. 5. Pp. 28-43 (In Russ).

Gladyshev S.A., Tsybankov A. A., Kandyba A. V. Verhnepaleoliticheskie kompleksy severnoj Mongolii: edinstvo i variabel'nost' [The Initial Upper Paleolithic Assemblages of Northern Mongolia: Cultural Unity and Variability]. Vestnik NGU. Seriya: Istoriya, filologiya [Newsletter of Novosibirsk State University. Series: History, Philology]. 2010. Vol. 5. Pp. 97 110 (In Russ).

Kanomata Y., Murata H., Umekawa T., Hong H., Yanagida T., Akoshima K., Suzuki M., Inoue I., Hayase R., Ohara K. Study of Cave Sites in Kyushu Region: Report of the Third Term Excavation at the Fukui Cave // Bulletin of the Tohoku University Museum. 2015. Vol. 14. P. 5-200 (In Japanese).

Khatsenovich A. M., Rybin E. P. Geometricheskie izdeliya v pozdnem verhnem paleolite Mongolii [The Geometric Tools in the Late Upper Paleolithic of Mongolia]. Problemy arheologii, etnografii, antropologii Sibiri i sopredel'nyh territorij [Problems of Archaeology, 
Ethnography, Anthropology of Siberia and Neighboring Territories]. Vol. 21. Novosibirsk : Izd-vo In-ta arheologii i etnografii SO RAN, 2015. Pp. 161-165 (In Russ).

Khatsenovich A. M., Rybin E.P., Gunchinsuren B., Olsen J. W., Shelepaev R. A., Zotkina L. V., Bolorbat T., Popov A. Y., Odsuren D. New Evidence for Paleolithic Human Behavior in Mongolia: The Kharganyn Gol 5 site // Quatenary International. 2017. Vol. 442. P. 78-94. DOI: 10.1016/j.quaint.2016.10.013.

Khatsenovich A. M., Rybin E.P., Pavlenok G. D., Anojkin A.A., Kharevich V.M., Gunchinsuren B., Bolorbat T., Odsuren D., Kulik N. A., Popov A. Yu. Zaklyuchitel'nyj etap polevyh issledovanij mnogoslojnogo paleoliticheskogo pamyatnika Harganyn-Gol-5 v Severnoj Mongolii [The Final Field Research of Kharganyn Gol 5 the Multilayer Paleolithic Site in Northern Mongolia]. Problemy arheologii, etnografii, antropologii Sibiri i sopredel'nyh territorij [Problems of Archaeology, Ethnography, Anthropology of Siberia and Neighboring Territories]. Vol. 21. Novosibirsk : Izd-vo In-ta arheologii i etnografii SO RAN, 2015. Pp. 166170 (In Russ).

Kolobova K. A., Krivoshapkin A. I., Pavlenok K. K. Carinated Pieces in Paleolithic Assemblages of Central Asia // Archaeology, Ethnology \& Anthropology of Eurasia. 2014. Vol. 4 (60). Pp. 13-29.

Rybin E. P. Tools, Beads, and Migrations: Specific Cultural Traits in the Initial Upper Paleolithic of Southern Siberia and Central Asia // Quatenary International. 2014. Vol. 347. P. 39-52. DOI: 10.1016/j.quaint.2014.04.031

Rybin E. P., Gladyshev S. A., Tsybankov A.A. Vozniknovenie i razvitie «otshchepovyh» industrij rannej pory verhnego paleolita Severnoj Mongolii [Origin and Evolution of "Flake" Industries of the Early Upper Paleolithic of Northern Mongolia]. Severnaya Evraziya v chetvertichnyj period: chelovek, paleotehnologii, geologiya, etnologiya i antropologiya [Northern Eurasia in the Quaternary Period: Man, Paleotechnologies, Geology, Ethnology, and Anthropology]. Irkutsk: Ottisk, 2007. Pp. 137-153. (In Russ).

Rybin E. P., Khatsenovich A. M., Gunchinsuren B., Olsen J. W., Zwyns N. The Impact of the LGM on the Development of the Upper Paleolithic in Mongolia // Quatenary International. 2016a. Vol. 425. Pp. 69-87. DOI:10.1016/j.quaint.2016.05/001

Rybin E. P., Khatsenovich A. M., Kandyba A. V. Paleoliticheskoe zaselenie Mongolii po dannym absolyutnoj hronologii [Pleistocene Settling of Mongolia: according to the Data of Absolute Chronology]. Izvestiya Altajskogo gosuniversiteta. Istoriya i arheologiya [Bulletin of Altai State University. History and Archaeology]. 2016b. Vol. 2. P. 245-254. DOI: 10.14258/ izvasu(2016)2-44 (In Russ)

Rybin E. P., Khatsenovich A. M., Pavlenok G.D. Posledovatel'nost' razvitiya industrij rannego - pozdnego verhnego paleolita Mongolii [The Sequence of Cultural Development of the Early-Late Paleolithic Industries in Mongolia]. Izvestiya Irkutskogo gosuniversiteta. Seriya: Geoarheologiya, etnologiya, antropologiya [Bulletin of Irkutsk State University. Series: Geoarchaeology, Ethnology, Anthropology]. 2016c. Vol. 16. Pp. 3-23 (In Russ).

Rybin E.P., Zenin A.N., Gladyshev S.A., Tsybankov A. A., Chargynov T. T. Intensivnost' ktilizacii kamennogo syr'ya i proizvodstvennaya deyatel'nost' cheloveka $\mathrm{v}$ rannej pore verhnego paleolita Severnoj Mongolii (po materialam stoyanki Tolbor) [Lithic Raw Material Utilization Intensity and Human production Activity in the Early Upper Paleolithic of Northern Mongolia 
(By the Materials of Tolbor 4 Site)]. Izvestiya laboratorii drevnih tehnologij [Newsletters of the Laboratory of Ancient Technologies]. Vol. 4. Irkutsk : Izd-vo Irkutskogo gosudarstvennogo tehnicheskogo universiteta, 2006. Pp. 201-218 (In Russ).

Sato H., Izuho M., Morisaki K. Human Cultures and Environmental Changes in the Pleistocene-Holocene Transition in the Japanese Archipelago // Quatenary International. 2011. Vol. 237. Pp. 93-102. DOI: 10.1016/j.quaint.2011.01.006

Slavinsky V.S., Rybin E. P., Belousova N. E. Variation in Middle and Upper Paleolithic Reduction Technology of Kara-Bom, the Altai Mountains: Refitting Studies // Archaeology, Ethnology \& Anthropology of Eurasia. 2016. Vol. 1 (44). P. 39-50. DOI: 10.17746/1563-0102.2016.44.1.039-050

Tabarev A. V. Blades and Microblades, Percussion and Pressure: Towards the Evolution of Lithic Technologies of the Stone Age Period, Russian Far East // The Emergence of Pressure Blade Making: From Origin to Modern Experimentation. New York: Springer, 2012. Pp. 329-346.

\section{БИБЛИОГРАФИЧЕСКИЙ СПИСОК}

Гладышев С. А., Гунчинсурэн Б., Джалл Э. Д., Доганджич Т., Звинс Н. П., Олсен Д. В., Ричардс М.П., Табарев А. В., Таламо С. Радиоуглеродное датирование палеолитических стоянок в долине р. Их-Тулбэрийн-Гол в Северной Монголии // Вестник НГУ. Серия: История, филология. 2013. Т. 12. С. 44-48.

Гладышев С. А., Табарев А.В. Некоторые проблемы изучения микропластинчатого расщепления в раннем верхнем палеолите Северной Монголии // Теория и практика археологических исследований. 2017. Т. 17. С. 154-166. DOI: 10.14258/tpai(2017)1(17).-11

Гладышев С. А., Табарев А. В. Заселение Японского архипелага и особенности каменных индустрий позднего палеолита сопредельных территорий: обзор современной проблематики // Stratum plus. 2020. №1. С. 117-136.

Гладышев С. А., Табарев А. В., Олсен Д. В. Итоги изучения верхнего палеолита Северной Монголии // Вестник НГУ. Серия: История, филология. 2011. № 5. С. 28-43.

Гладышев С. А., Цыбанков А. А., Кандыба А. В. Верхнепалеолитические комплексы северной Монголии: единство и вариабельность // Вестник НГУ. Серия: история, филология. 2010. № 5. С. 97-110.

Деревянко А.П., Зенин А.Н., Рыбин Е.П., Гладышев С.А., Цыбанков А. А. Развитие каменных индустрий верхнего палеолита Северной Монголии (по данным стоянки Толбор) // Человек и пространство в культурах каменного века Евразии. Новосибирск : Изд-во Ин-та археологии и этнографии СО РАН, 2006. С. 17-42.

Рыбин Е.П., Гладышев С. А., Цыбанков А. А. Возникновение и развитие «отщеповых» индустрий ранней поры верхнего палеолита Северной Монголии // Северная Евразия в четвертичный период: человек, палеотехнологии, геология, этнология и антропология. Иркутск : Оттиск, 2007. С. 137-153.

Рыбин Е. П., Хаценович А. М., Кандыба А. В. Палеолитическое заселение Монголии по данным абсолютной хронологии // Известия Алтайского госуниверситета. История и археология. 20166. № 2. С. 245-254. DOI: 10.14258/izvasu(2016)2-44 
Рыбин Е.П., Хаценович А. М., Павленок Г.Д. Последовательность развития индустрий раннего - позднего верхнего палеолита Монголии // Известия Иркутского госуниверситета. Серия: Геоархеология, этнология, антропология. 2016 в. № 16. С. 3-23.

Рыбин Е. П., Зенин А.Н., Гладышев С. А., Цыбанков А. А., Чаргынов Т. Т. Интенсивность ктилизации каменного сырья и производственная деятельность человека в ранней поре верхнего палеолита Северной Монголии (по материалам стоянки Толбор) // Известия лаборатории древних технологий. Иркутск : Изд-во Иркутского государственного технического университета, 2006. Вып. 4. С. 201-218.

Хаценович А. М., Рыбин Е. П. Геометрические изделия в позднем верхнем палеолите Монголии // Проблемы археологии, этнографии, антропологии Сибири и сопредельных территорий. Новосибирск : Изд-во Ин-та археологии и этнографии СО РАН, 2015. T. XXI. C. 161-165.

Хаценович А. М., Рыбин Е.П., Павленок Г. Д., Анойкин А. А., Харевич В. М., Гунчинсурэн Б., Болорбат Ц., Одсурэн Д., Кулик Н. А., Попов А. Ю. Заключительный этап полевых исследований многослойного палеолитического памятника Харганын-Гол-5 в Северной Монголии // Проблемы археологии, этнографии, антропологии Сибири и сопредельных территорий. Новосибирск : Изд-во Ин-та археологии и этнографии СО PAH, 2015. T. XXI. C. 166-170.

Buvit I., Izuho M., Terry K., Konstantinov M. V., Konstantiniov A. V. Radiocarbon Dates, Microblades and Late Pleistocene Human Migrations in the Transbaikal, Russia and the PaleoSakhalin-Hokkaido-Kuril Peninsula // Quatenary International. 2016. Vol. 425. P. 100-119. DOI: 10.1016/j.quaint.2016.02.050

Derevianko A. P., Gladyshev S. A., Olsen J. W., Petrin V.T., Tserendagva Y. Characteristic Features of the Chikhen Agui Lithic Assemblage (Gobi Altai) // Archaeology, Ethnology \& Anthropology of Eurasia. 2001. Vol. 5. P. 25-39.

Derevianko A. P., Zenin A. N., Rybin E.P., Gladyshev S. A., Tsybankov A. A., Olsen D., Tseveendorj D., Gunchinsuren B. The Technology of Early Upper Paleolithic Lithic Reduction of Northern Mongolia: the Tolbor-4 Site // Archaeology, Ethnology \& Anthropology of Eurasia. 2007. Vol. 29. P. 16-38.

Derevianko A. P., Markin S. V., Gladyshev S. A., Olsen D. The Early Upper Paleolithic of the Gobi Altai Region in Mongolia (Based on Materials from the Chikhen-2 Site) // Archaeology, Ethnology \& Anthropology of Eurasia. 2015. Vol. 3 (43). P. 7-41. DOI: 10.1016/j. aeae.2015.11.004

Derevianko A. P., Olsen D., Tseveendorj D., Krivoshapkin A. I., Petrin V. T., Brantingham P. J. The Stratified Cave Site of Tsagaan Agui in the Gobi Altai (Mongolia) // Archaeology, Ethnology \& Anthropology of Eurasia. 2000. Vol. 1. P. 23-36.

Derevianko A. P., Rybin E. P., Gladyshev S. A., Tsybankov A.A., Gunchinsuren B., Olsen D. Early Upper Paleolithic Stone Tool Technologies of Northern Mongolia: the Case of Tolbor-4 and Tolbor-15 // Archaeology, Ethnology \& Anthropology of Eurasia. 2013. Vol. 4 (56). P. 21-37.

Gillam J. C., Gladyshev S. A., Gunchinsuren B., Olsen J. W., Tabarev A. V., Rybin E. P., 2014. Update on Paleolithic Research in Northern Mongolia // Legacy. 2014. Vol. 2. P. 22-23. 
Gladyshev S. A., Olsen J. W., Tabarev A. V., Kuzmin Y. V. Chronology and Periodization of Upper Paleolithic Sites in Mongolia // Archaeology, Ethnology \& Anthropology of Eurasia. 2010. Vol. 3 (43). P. 33-40.

Gladyshev S.A., Olsen J.W., Tabarev A. V., Jull A. J. The Upper Paleolithic of Mongolia: Recent Finds and New Perspectives // Quatenary International. 2012. Vol. 281. P. 36-46. DOI: 10.1016/j.guaint.2012.01.032

Gladyshev S. A., Tabarev A. V. New Data on the Early Upper Paleolithic of Northern Mongolia // Current Research in the Pleistocene. 2009. Vol. 26. P. 17-18.

Kanomata Y., Murata H., Umekawa T., Hong H., Yanagida T., Akoshima K., Suzuki M., Inoue I., Hayase R., Ohara K. Study of Cave Sites in Kyushu Region: Report of the Third Term Excavation at the Fukui Cave // Bulletin of the Tohoku University Museum. 2015. Vol. 14. P. 5-200 (In Japanese).

Khatsenovich A. M., Rybin E.P., Gunchinsuren B., Olsen J. W., Shelepaev R. A., Zotkina L. V., Bolorbat T., Popov A. Y., Odsuren D. New Evidence for Paleolithic Human Behavior in Mongolia: The Kharganyn Gol 5 site // Quatenary International. 2017. Vol. 442. P. 78-94. DOI: 10.1016/j.quaint.2016.10.013.

Kolobova K. A., Krivoshapkin A. I., Pavlenok K. K. Carinated Pieces in Paleolithic Assemblages of Central Asia// Archaeology, Ethnology \& Anthropology of Eurasia. 2014. Vol. 4 (60). P. 13-29.

Rybin E. P. Tools, Beads, and Migrations: Specific Cultural Traits in the Initial Upper Paleolithic of Southern Siberia and Central Asia // Quatenary International. 2014. Vol. 347. P. 39-52. DOI: 10.1016/j.quaint.2014.04.031

Rybin E. P., Khatsenovich A. M., Gunchinsuren B., Olsen J. W., Zwyns N. The Impact of the LGM on the Development of the Upper Paleolithic in Mongolia // Quatenary International. 2016a. Vol. 425. P. 69-87. DOI:10.1016/j.quaint.2016.05/001

Sato H., Izuho M., Morisaki K. Human Cultures and Environmental Changes in the Pleistocene-Holocene Transition in the Japanese Archipelago // Quatenary International. 2011. Vol. 237. P. 93-102. DOI: 10.1016/j.quaint.2011.01.006

Slavinsky V.S., Rybin E. P., Belousova N. E. Variation in Middle and Upper Paleolithic Reduction Technology of Kara-Bom, the Altai Mountains: Refitting Studies // Archaeology, Ethnology \& Anthropology of Eurasia. 2016. Vol. 1 (44). P. 39-50. DOI: 10.17746/1563-0102.2016.44.1.039-050

Tabarev A. V. Blades and Microblades, Percussion and Pressure: Towards the Evolution of Lithic Technologies of the Stone Age Period, Russian Far East // The Emergence of Pressure Blade Making: From Origin to Modern Experimentation. New York : Springer, 2012. P. 329-346. 


\section{INFORMATION ABOUT THE AUTHORS / ИНФОРМАЦИЯ ОБ АВТОРАХ}

Dr. Andrey V. Tabarev is Leading Research Fellow, Division of Foreign Archaeology, Head, Institute of Archaeology and Ethnography, Russian Academy of Sciences, Siberian Branch, Novosibirsk, Russian Federation.

Табарев Андрей Владимирович, доктор исторических наук, ведущий научный сотрудник Института археологии и этнографии СО РАН, г. Новосибирск, Российская Федерация.

Dr. Sergey A. Gladyshev is Senior Research Fellow, Department of the Archaeology of the Stone Age, Institute of Archaeology and Ethnography, Russian Academy of Sciences, Siberian Branch, Novosibirsk, Russian Federation

Гладышев Сергей Анатольевич, кандидат исторических наук, старший научный сотрудник Института археологии и этнографии СО РАН, г. Новосибирск, Российская Федерация.

Материал поступил в редколлегию 28.06. 2021.

Статья принята в номер 30.08.2021. 